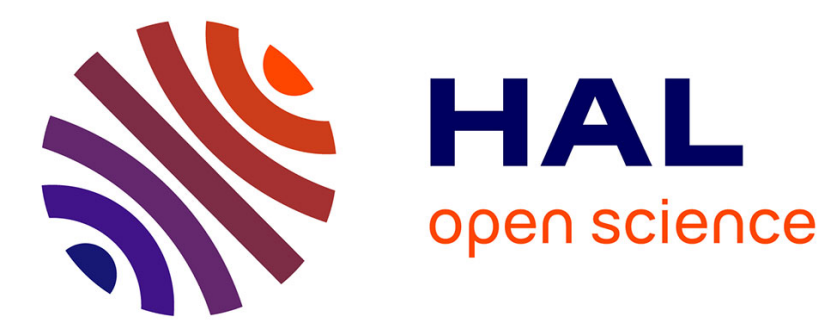

\title{
Co-creating and directing Innovation Ecosystems? NASA's changing approach to public-private partnerships in low-earth orbit
}

\author{
Mariana Mazzucato, Douglas K. R. Robinson
}

\section{To cite this version:}

Mariana Mazzucato, Douglas K. R. Robinson. Co-creating and directing Innovation Ecosystems? NASA's changing approach to public-private partnerships in low-earth orbit. Technological Forecasting and Social Change, 2017, 10.1016/j.techfore.2017.03.034 . hal-01703940

\author{
HAL Id: hal-01703940 \\ https://hal.science/hal-01703940
}

Submitted on 3 May 2020

HAL is a multi-disciplinary open access archive for the deposit and dissemination of scientific research documents, whether they are published or not. The documents may come from teaching and research institutions in France or abroad, or from public or private research centers.
L'archive ouverte pluridisciplinaire HAL, est destinée au dépôt et à la diffusion de documents scientifiques de niveau recherche, publiés ou non, émanant des établissements d'enseignement et de recherche français ou étrangers, des laboratoires publics ou privés. 
Please cite as: Mazzucato, M., \& Robinson, D. K. (2018). Co-creating and directing Innovation Ecosystems? NASA's changing approach to public-private partnerships in low-earth orbit. Technological Forecasting and Social Change, 136, 166-177.

\title{
Co-creating and directing Innovation Ecosystems?
}

\section{NASAs changing approach to public-private partnerships in low-earth orbit}

\author{
Mariana Mazzucato ${ }^{1,2}$ and Douglas K.R. Robinson ${ }^{1,3 *}$ \\ 1 Institute for Innovation and Public Purpose, University College London, UK \\ 2 Science Policy Research Unit (SPRU), University of Sussex, UK \\ 3 Laboratoire Interdisciplinaire Sciences Innovations Sociétés (LISIS), CNRS-INRA-ESIEE-UPEM, \\ Université Paris-Est Marne-la-Vallée, France \\ * Corresponding author: contact@douglas-robinson.com
}

\begin{abstract}
A recent report from NASA's office of the chief technologist positions a self-sustained "low-earth-orbit ecosystem" as a desirable objective for NASA's human spaceflight policy and linking to its larger aims of deeper exploration of the solar system. The report follows a wave of mission shifts and space policy directives which emphasize that the private sector should be given more power and receive public agency financial support to stimulate space services. To understand how US space innovation activities are changing, and to be able to make assessments and policy recommendations, we use an innovation ecosystems approach to help understand the types of relationships between actors in low-earth-orbit and to determine the ramifications for US space policy. Our findings reveal four new forms of relationships between NASAA and other parties in the emerging innovation ecosystem and we discuss how these lead to policy challenges for NASA as a mission-oriented public agency with the new additional objective of creating an economic zone in orbit.
\end{abstract}

\section{Introduction}

Historically, NASA's mission-oriented programs for innovation have been driven by security concerns and by the need for maintaining technical leadership over other nations. The situation is now shifting. NASA is attempting to create new markets that fuel a sustainable Earth-LEO economy, or, as Sam Scimemi, director of the ISS, put it, to "sustain economic activity in LEO enabled by human spaceflight, driven by private investments, creating value through commercial supply and demand" where the "destiny of LEO beyond ISS is in the hands of private industry outside the government box."

A recent report from NASA's office of the chief technologist, the drive towards a self-sustained "lowearth-orbit ecosystem" has been positioned as a desirable objective for NASA's human spaceflight policy

1 Presentation given by Sam Scimemi at NASA Headquarters Washington, DC December 10, 2014; http://www.nasa.gov/sites/default/files/files/NASA_Sam_Scimemi.pdf 
and linking to its larger aims of deeper exploration of the solar system (see Emerging Space report pp4). ${ }^{2}$ The report comes after a wave of mission shifts and space policy directives which emphasis that the private sector should be given more power and be supported to stimulate space services. There is also evidence of actual activities stemming from these policy changes, for example the first fully commercial launches of cargo to the international space station by SpaceX and Orbital-ATK, along with other commercial service providers onboard the ISS such as microgravity experiment services (NanoRacks) and in-orbit 3D printing virtually controlled by the private firm Made-In-Space (where NASA does not own the onboard printer).

There is a growing emphasis and action on stimulating/creating a low-earth-orbit economy, where markets will produce economic benefits for the US as well as a low-earth-orbit industry that can provide services for NASA when needed. However there are also indications that the way the shift towards an ecosystem approach is being actioned by NASA is leading away from a "market creation" approach, to something resembling a "fixing market failure" approach (Mazzucato 2015). ${ }^{3}$ Indeed, at first glance, it seems that NASA has moved from a role as dominant director of innovation and development with active mission-oriented polices (Foray et al 2012) towards more diffusion-based policies (Chiang 1991) where their role is to support the creation of the right conditions for markets to emerge (a standard market failure approach). This support role focuses on catalyzing an "innovation ecosystem" with a mix of private, not-for-profit, and public actors in LEO. ${ }^{4}$

In this paper, in line with the focus of this special issue, we take an innovation ecosystem approach to understand (a) the changing population of the low-earth-orbit ecosystem, (b) the forms and functions of the relationships that connect between members of this population and (c) use these findings to understand the changing relationship between NASA and low-earth-orbit human spaceflight activities. Innovation ecosystems require different types of policies. Vertical policies are more directional and 'active' focusing on directing change. ${ }^{5}$ Horizontal policies are more focused on the background or framework conditions necessary for innovation, allowing the direction to be set by the private sector. ${ }^{6}$ While both horizontal and vertical policies are required, it can be said that horizontal policies are more

2 http://www.nasa.gov/sites/default/files/files/Emerging_Space_Report.pdf

${ }^{3}$ Market failure theory takes the 'First Fundamental Theorem' (FFT) of welfare economics (Arrow 1951) as the starting point. The FFT states that markets are the most efficient allocators of resources under three specific conditions: (1) There is a complete set of markets, so that all supplied/demanded goods and services are traded at publicly known prices; (2) all consumers and producers behave competitively (that is, all agents are price-takers); and (3) an equilibrium exists. Under these three conditions, the allocation of resources by markets is Pareto-optimal (no other allocation will make a consumer or producer better off without making someone else worse off).

${ }^{4}$ In this paper, when we describe NASA policies, we focus on those related to human spaceflight and operations in low-Earth orbit (LEO). The focus of the study is on human-spaceflight based activities in low-earth-orbit (LEO) a region of space stretching from $160 \mathrm{~km}$ to $2000 \mathrm{~km}$ from the Earths surface. Aside from the 24 astronauts that flew to the Moon during the Apollo program, all human space activities have been restricted to this region of space. It is the location of the International Space Station, and is distinct (at present) from sub-orbital space flights, which at the moment just break the $100 \mathrm{~km}$ altitude limit. This is not the full scope of NASA's activities, of course, which also include deepspace scientific missions, aeronautics, planetary landers, etc. For full details, see www.nasa.gov.

${ }^{5}$ Vertical approaches to innovation policy focus on direct investments (in both basic and applied areas) on specific technologies and sectors (e.g. biotechnology, nanotechnology, clean-technology), and financing specific firms through public venture capital or public loans. Vertical policies determine not only improve the occurrence of innovation but also guide 'direction'- determining the boundaries within which private sector innovation and experimentation can happen.

${ }^{6}$ Horizontal approaches to innovation policy focus on (a) creating the framework conditions for innovation through the background (necessary) conditions, e.g. education, science-industry links, fundamental research and infrastructures; and (b) supporting innovation in the private sector, through indirect measures such as tax incentives. The horizontal approach tends to rely on the 'market' to decide the direction of change. 
about 'facilitating' innovation in the private sector, while vertical policies embody a more active role for the public sector in directing change not only facilitating it, often through missions which require actively creating and shaping markets - not only fixing them (Mazzucato, 2015). We shall return to this in the conclusions

In the following section we draw on the literature around systems of innovation to help us create an innovation ecosystem "lens" to probe into the changes that are occurring both within NASAs space policy regarding low-earth orbit, and the multi-actor activities (actual and planned) in low-earth orbit. With this in mind, section 2 will also describe how we will use this meso-level model of the innovation ecosystem to help us connect the broader US human spaceflight policy (macro) with the individual activities of firms and other organizations in low-earth-orbit (micro). Section 3 will describe the emergence of US human spaceflight during NASA's first 5 decades of activity, detailing the nature of the bi-lateral relationships between NASA and other parties, where NASA is the central organizers of US human spaceflight in LEO. Section 4, will dig deeper into how this has shifted from a single actor space, to an emerging innovation ecosystem, detailing the new forms of relationships between NASA and other actors in LEO. Section 5 will explore the ramifications of the emerging ecosystem for US human spaceflight policy, particularly for LEO.

\section{Models of actor ecologies in innovation}

Innovation in technology-based sectors is rarely done by a single organization alone; these fields are characterized by complex organizational networks which address different aspects of innovation. In the literature on innovation in technology-based sectors, the complex division of labor has been modelled in terms of innovation chains (sometimes called value chains), networks and systems. While some of these concepts build on each other, they have their relative merits and limitations. Below we review, briefly, this literature in order to locate our ecosystem approach.

\subsection{Value chains and networks}

The concept of the value chain is used in strategic analysis: as a tool it has been used for three decades now to analyze the firm, its major competitors, and their respective performances, in order to identify and address performance gaps (Peppard \& Rylander 2006, Porter 2001). A value chain is 'the series of activities required to produce and deliver a product or service' (Porter 2001:11). The chain is constituted around the activities required to produce it, from raw materials to the ultimate consumption of the finished product. Layers in a value chain have been described in terms of a sequence comprising suppliers, manufacturers, distributors, and consumers. For example, one of the more well-researched chains - the wireless communication (mobile phone) chain, includes equipment companies; infrastructure companies/network operators; Steinbock 2003), which interact with a multitude of specialized companies (software intermediaries; financial intermediaries; content providers; resellers; cf Peppard \& Rylander 2006); which in turn engage with the end customer (Li \& Whalley 2002). Scanlon (2009) includes a 'reverse supply chain', which re-connects the user with the original equipment manufacturer whenever phones are returned for repair or disposal. In semiconductor manufacturing, the main engineering and manufacturing tasks that involve integrated circuit (IC) design, (physical) manufacturing, and systems integration of these ICs (cf Lee \& von Tunzelmann 2005), have over the past three decades become organizationally separated; different companies address different parts of the chain (design houses; mask houses; wafer companies; pure-play foundries; and back-end processing and electronic packaging. Within innovation chains we observe interactions both within the same layer ('horizontal' transactions) but also between layers ('vertical' ties), such as logistics management and contractual arrangements between 
buyers and suppliers (Lazzarini et al 2001, cf also Saliola \& Zanfei 2009, Omta et al 2001). Both in terms of the actors (organizations and their relationships) and technologies, chains can be seen as dynamic: they undergo changes related to co-evolution of innovation, relationships between actors in the value network, services offered (cf the adoption of new functionalities), and customer relationships (Peppard \& Rylander 2006). The concept of value chains has come under scrutiny for certain limitations (cf Fransman 2002), and alternatives have been proposed in various bodies of literature, such as network concepts which highlight cooperative rather than hierarchical behaviors in inter-firm relationships (cf Peppard \& Rylander 2006, Funk 2009, Li \& Whalley 2002).

\subsection{Innovation systems}

Another strand of research on innovation actor ecologies, broadly as innovation systems analysis, integrates (extensive) quantitative analysis with testing of the impact of particular actors or instruments on the innovation process within the system and relative to other national systems (Lee \& von Tunzelmann 2005). Systems of innovation have been defined as "the network of institutions in the public and private sectors whose activities and interactions initiate, import, modify and diffuse new technologies" (Freeman 1995), or "the elements and relationships which interact in the production, diffusion and use of new, and economically useful, knowledge" (Lundvall, 1992, p. 2). Distinctions are made between a national, local, and sectoral innovation systems (Malerba 2002). Lee \& von Tunzelmann (2005) describe a model of a national innovation system that comprises five actors (government, industry (firms), research institutes (public and private), foreign companies, and universities) (Lee \& von Tunzelmann 2005). Malerba (2002) distinguishes in his definition of a sectoral system of innovation and production, firm type organizations (users, producers and input suppliers) and non-firm organizations (e.g. universities, financial institutions, government agencies, trade-unions, or technical associations). A 'sectoral' innovation system would focus on an industry sector - such as telecom equipment and services (for case studies of each sector, cf Malerba 2003). Such an industry sector perspective broadens the firm- or supplier/assembler networkcentric view of value chains to include development- and market-external actors, such as institutions assumed to be impacting on the dynamics of innovation. The assumption is that the factors impacting the diffusion of innovations are located both in innovation chains/networks, the market place, and the regulatory regime (including industrial, national, or international authorities that can influence activities in the innovation system, the marketplace, and/or the regulatory regime; Tilson \& Lyytinen 2004, Ansari \& Garud 2009).

\subsection{Innovation Ecosystems}

Innovation systems (whether sectoral, regional, or national) embody dynamic links between various innovation actors and institutions (firms, financial institutions, research/education, public sector funds, and intermediary institutions), as well as links within organizations and institutions (Freeman, 1995). The most important question then is how actors come to interact: what are the reasons behind certain research results being taken up, or certain innovation trajectories being followed? As most actors do not have perfect knowledge of neither the future nor developments around them, their uptake behavior can be described as iterative and tentative: responses and solutions are being sought. Decisions spring forth from these interactions; in order to understand the decisions, these processes must be studied (Stirling, 2009; Smith et al., 2005; Robinson and Propp, 2008). The above models (innovations systems and value chains), while being able to capture and map relevant actors do not necessarily provide methodologies to understand how decision making at the level of actor-actor relationships are occurring. This requires further insights from other bodies of literature.

Although there is incoherence in the definition of "innovation ecosystems" in the literature, our model of innovation ecosystems falls into the multi-actor perspective category of recent review of innovation 
ecosystems (Tsujimoto et al 2015), where a variety of actors interact in a bounded "interaction space" where socio-economic value is created through research, novelty creation, traditional market activities. This perspective is neither macro nor micro, but more meso, where individual firms are seen as part of a broader network of firms with whom they cooperate and compete (Robinson, 2014). From the mesoperspective, the network of actors and their relationships - not the firm - is the unit of analysis (Chesborough et al. 2014, Rohrbeck et al. 2009, Autio et al. 2014). The network consists of customers, subcontractors, infrastructure, suppliers, competencies, or functions and the links or relationships between them. The competencies that generate innovation are part of a collective activity occurring through a network of actors and their links or relationships .Green et al 1999, describe this as an intermediary zone between broad techno-economic paradigms (Perez 1983, Freeman 1994, Perez 2004) and technoeconomic networks (Callon et al 1992, Laredo et al. 2001) where "construction of particular constellations of public and private institutions, such as campaigning groups, government agencies, academic scientists and business firms" and "the meso-level techno-economic might involve analysis of the inter-related processes involved in the construction of markets and the evolution of demand" (Green et al. 1999, pp29).

The ecosystem approach complements the systems of innovation perspective because it focuses on the nature of the relationships between actors. These can be, for example, parasitic (or even predator-prey) or mutualistic. In natural ecosystems, symbiotic relationships can take one of three forms: (i) mutually beneficial relationships in which each partner benefits (mutualism), (ii) relationships in which one partner benefits and the other remains unaffected (commensalism), and (iii) relationships in which one partner benefits whilst negatively affecting the other (parasitism) (Offenberg 2001) ${ }^{7}$. An innovation ecosystem does not stay static, it is built on the nature of the linkages and partnerships between actors. Moreover, the strategies of the actors may change, for example for large public agencies such as NASA and the NIH, the nature of the investments in partnerships with other actors changes when their core mission changes.

Such a meso-level perspective captures the nature of the relationships between actors, and also captures the essence of the system which shapes the micro and relates to the macro. In the remainder of the paper, for the case of Low-Earth Orbit, we can describe this meso-level as a "space" where infrastructures and technological innovations are being developed in an innovation ecosystem, both defined and driven by public-private partnerships between the (often international) players with connections to the micro-level (through R\&D in labs such as the International Space Station itself, or national public laboratories) and to national systems of innovation (for example, NASA as a mission-oriented public agency in the United States National Innovation System).

\section{NASAs human spaceflight activities in low-earth orbit 1958 - 2015}

The nature of NASA's relationship with other actors is rooted in the very earliest stages of its existence. The formation of NASA in mid-1958 was a direct response to the launch of the Soviet Sputnik 1 the previous autumn, and was officially launched with the signing of the National Aeronautics and Space Act (Hall 1992). The space act focused on creating a centralized organization that would coordinate and consolidate a nation-wide infrastructure for space exploration and exploitation (Stares 1983). The original National Aeronautics and Space Act laid out a number of goals for the US civilian space program that NASA would coordinate (NRC 2014):

- To expand knowledge of the atmosphere and space

- To improve the performance and efficiency of launchers and spacecraft

- To gain knowledge in the development and operation of space vehicles

${ }^{7}$ For an extended discussion of the danger of parasitic innovation eco-systems, see Mazzucato (2013) chapters 1, 8 \& 9). 
- To develop long-term strategies that incorporate the analysis of the potential benefits and opportunities to be had and the problems involved ${ }^{8}$

- To build and maintain leadership aerospace and space technology

- To cooperate with the DoD as and when required

- To foster international cooperation

- To exploit the scientific and technological achievements for the benefit of the nation.

As the Soviet space program continued to develop faster and further with the launch of Vostok in April 1961, US space policy came into focus with President Kennedy's announcement in May 1961 of the US government's aim to "land a man on the Moon within the decade". ${ }^{9}$ With a clear objective and a supportive Congress, the 1960s saw the growth of NASA along with a private sector that would construct and co-develop the technologies that led to US astronauts landing on the moon in 1969 (Grimwood et al. 1969). One of the earliest examples of involving companies, from 1958 to the lunar landings just over a decade later, was McDonnell Aircraft Corporation, which was the prime contractor for both the Mercury and Gemini capsules. For the Apollo missions, IBM technicians at the Marshall Space Center created the guiding instrument unit used in the Saturn rockets, as well as developing the network of relay stations and ships to track and communicate with the Apollo spacecraft. ${ }^{10}$ Grumman Corporation designed, assembled, integrated, and tested the Lunar Module, six of which carried astronauts to the moon. ${ }^{11}$ During this period, NASA kept control of innovation policy: the private sector was overseen and directed by NASA throughout the Mercury, Gemini, and eventually the Apollo programs, which would see six landings on the Moon between 1969 and 1972. The contracts were known as Federal Acquisition Regulations (FAR) cost-plus contracts. NASA defined the requirements of the contracts and the contractors presented an extensive proposal to deliver these requirements. Once the specifications were agreed to, any changes, regardless of their origin, required NASA to pay more for such additions. ${ }^{12}$ The use of FAR cost-plus contracts shifted the budgetary burden and risk of delays to NASA, with little incentive for the contracted party to keep to schedule (Pittman and Rasky 2013) and thus time and cost overruns were common place.

In 1969, the Space Task Group (STG), headed by the US Vice President Spiro Agnew, produced a report that would direct NASA missions into 1970s post-Apollo. ${ }^{13}$ The incoming president, Richard Nixon, repositioned the space budget as part of a larger system with other national priorities, the outcome of which was the civil space budget being reduced by 25 percent by 1973 (NRC 2014). During this transition, Apollo technologies and infrastructures were applied to the Skylab space station (1973-1974) and the last flight of an Apollo spacecraft with the docking to a Soviet Soyuz space craft in the summer of 1975. With the STG's proposals for the post-Apollo program to include a space station, a mission to Mars and a space shuttle program, the shuttle program seemed to be the "de facto policy" (Logsdon 1995) for a US civilian space program to satisfy the Nixon administration's wish to cut costs and maintain a civilian human spaceflight capability (Logsdon 1986, Launius 1994).

The scale-down and budget reductions of the mid-1970s meant a heavy focus on the shuttle fleet as a key innovation driver for human spaceflight and LEO operations, with the first Space Shuttle launch in 1981. The early 1980s saw a sense of a new approach in US space policy, one in which commercialization

\footnotetext{
${ }^{8}$ This translated into a key document published in 1959, which plotted a strategy of scientific research, technical infrastructure, and human space exploration. More details can be found here: http://www.senate.gov/artandhistory/history/resources/pdf/NASALongRange1959.pdf.

${ }_{9}$ Kennedy, J. F. (1962). John F. Kennedy Moon Speech, Rice Stadium.

10 http://www-03.ibm.com/ibm/history/ibm100/us/en/icons/apollo/

$11 \mathrm{http}: / /$ www.northropgrumman.com/AboutUs/OurHeritage/Pages/Inspace.aspx

${ }^{12}$ Also any delays in schedule by the contracted firm would have to be paid for by NASA.

${ }^{13}$ Space Task Group (1969), The Post-Apollo Space Program: Directions for the Future, NASA Historical Reference Collection, History Office, NASA Headquarters: http://www.hq.nasa.gov/office/pao/History/taskgrp.html.
} 
would play a much larger part. For example, President Reagan's National Space Policy including commercial aspects (1982) was followed by the establishment of the NASA Office of Commercial Programs in September of 1984. In the following month, he initiated the Commercial Space Launch Act, which aimed to support "the encouragement of the private sector in commercial space endeavors. Fragmentation and shared authority had unnecessarily complicated the process of approving activities in space." 14 The beginning of this enthusiasm for a larger and more intense relationship with the private sector had started a few years earlier, in 1979, with the then-NASA Administrator Robert Frosch creating "NASA Guidelines Regarding Early Usage of Space for Industrial Purposes" (Frosch 1979). Based on these guidelines, NASA developed three forms of cooperative agreements that would form the foundations of this increased interaction between NASA and the private sector. These included: (1) the Technical Exchange Agreement (TEA), which would enable the exchange of technical information and collaboration in joint research activities on Earth; (2) the Industrial Guest Investigator Agreement (IGI), which would enable an industrial researcher to collaborate in a NASA activity; and (3) the Joint Endeavour Agreements (JEAs), which were designed as early stage space ventures to demonstrate the value of space technology for market applications (Brown and Zoller 1981). ${ }^{15}$

The origins of what would become the International Space Station (ISS), for public and private use, began to emerge during the Reagan administration. NASA proposed a large space station in LEO that would be much than the Soviet Salyut program (1971-1982) and would compete with what would become Space Station Mir. The initial idea was to reinforce US progress in space and to exploit the commercial potential of low Earth orbit (Kay 1994). In his State of the Union speech in 1984, President Reagan announced that part of the US space policy would include "NASA to develop a permanently manned space station and to do it within a decade" (Kay 1994). With this pronouncement, the Space Station Freedom program was launched with a commercial space habitat module included in the design. It seemed that NASA was moving full steam ahead to catalyze the private-sector involvement and the creation of a space market. However, after the Challenger disaster of 1985, in which seven astronauts died, a dramatic policy shift occurred because of the large liability incurred due to the loss of cargo. This shift led to the reduction in private-sector payloads on the shuttle, which was the flagship NASA activity relating to the commercialization of space (Reagan 1986, National Commission on Space 1986). ${ }^{16}$ The diffuse culture of limiting commercial activity in LEO continued until the late 1980s. This became visible with the Industrial Space Facility (private space station) proposed by Space Industries Inc., ${ }^{17}$ where the proposal was defeated after a series of congressional hearings. NASA saw a private platform as a direct threat to Space Station Freedom (Space Station Operations Task Force 1987), which would later become part of the ISS. An exception to this was SpaceHab, which became the only private player to fly payloads in the shuttle. ${ }^{18}$

In the mid-1990s, "Shuttle Operations" transferred to private contractors. Lockheed Martin began work on next-generation shuttles X-33 as part of NASA's Space Launch Initiative (SLI), which involved private enterprise in the creation of launchers. In 1998, the US Congress passed the Commercial Space

\footnotetext{
14 President Reagan Statement on Signing the Commercial Space Launch Act October 30, 1984 : http://www.presidency.ucsb.edu/ws/?pid=39335

${ }^{15}$ Another cooperative agreement type was added for private use of the space shuttle. The Space Systems Development Agreement (SSDA), launched in 1985, allowed companies to acquire flights or services on the shuttle under special terms, including deferment of payment to later dates decided on a case-by-case basis (Rumerman 1999).

${ }^{16}$ One of the original rationales for the Space Shuttle was the transportation of commercial and defense-related cargos into space.

17 The CEO was the lead designer of the Mercury capsule and Space Shuttle and was therefore a respected insider.

${ }^{18}$ Established in 1984, Spachab Inc. provided modules that sat inside the cargo bay of the space shuttle, providing such capabilities for 22 space shuttle flights, including a payload during the Columbia disaster. Over its 20-year history, Spacehab has contracted more the 1 billion dollars through providing services to NASA. The company exists today under its new name Astrotech.
} 
Act, according to which the government was to "acquire space transportation services from US commercial providers when such services are required." This legislation also identified the economic development of the Earth-LEO innovation system as a priority of the ISS. This shift in priorities to include economic development of 'Earth orbital space' demonstrated a gear change in the inclusion of commercialization directly into the mission of NASA with regard to LEO and the ISS.

Until 2005, NASA, through its large programs and through its policies as a mission-oriented public agency, directed the development of human spaceflight. It coordinated the direction through tightly regulated FAR contracts (which they used since the Gemini program) where NASA would directly decide what technical solutions would be developed for their needs, which they would then finance directly. These were later complimented by cooperation agreements such as Technical Exchange Agreement (TEA) and Joint Endeavour Agreements (JEAs) which would help coordinate activities prior to full blown FAR contracts. Until the mid 2005s, US human spaceflight activities in low-earth-orbit where conducted on Amercian own space infrastructure built, and sometimes serviced, by US firms.

Over the last decade, an increasingly diverse constellation of actors has emerged in the LEO ecosystem. Examples of such new actors include privately constructed and operated Earth to orbit transportation systems, ${ }^{19}$ private-sector research and development activities on the International Space Station, actors constructing new in-orbit capabilities platforms designed and developed by the private sector, as well as private sector creating business services on the ISS, including the launching of cubesats, beaming realtime videos of the Earth and 3D printing services on station. This is in stark contrast with the situation just ten years ago. Figure 2 below illustrates this with a diagram of the LEO ecosystem with a focus on US human space exploration and exploitation in 2005 and $2015 .{ }^{20}$ The different colors represent the differences in the types of actors responsible for the activities in LEO.

Figure 2 shows three groups of activities in 2005: (1) access to LEO via the space shuttle fleet who design and development was directed by NASA and developed with private actors on a contractual basis; (2) ISS infrastructure and operations conducted by NASA; and (3) operations of what in 2005 was labeled as the ISS US National $\mathrm{Lab}^{21}$.

\section{Figure 2: US human space activities in the LEO ecosystem in 2005 and in 2015}

\footnotetext{
${ }^{19}$ Following the awarding of the Ansari X-prize in 2004, there is also growing number of and sub-orbital transport systems such as Virgin Galactic and XCOR (Kay 2011). We do not discuss these in this paper because they are not directly linked to Low-Earth-Orbit (being suborbital), though we acknowledge that they may play a role in the broader space economy.

20 The schematic represents the LEO ecosystem in terms of key elements, such as the ISS, launchers, use, etc., and provides some examples of the actors that are active in each area. It does have some limitations; for example, there are many more examples for the "National Lab Users" boxes and the implementation boxes, whereas the other boxes are quite exhaustive.

21 http://www.nasa.gov/mission_pages/station/research/nlab/index.html
} 

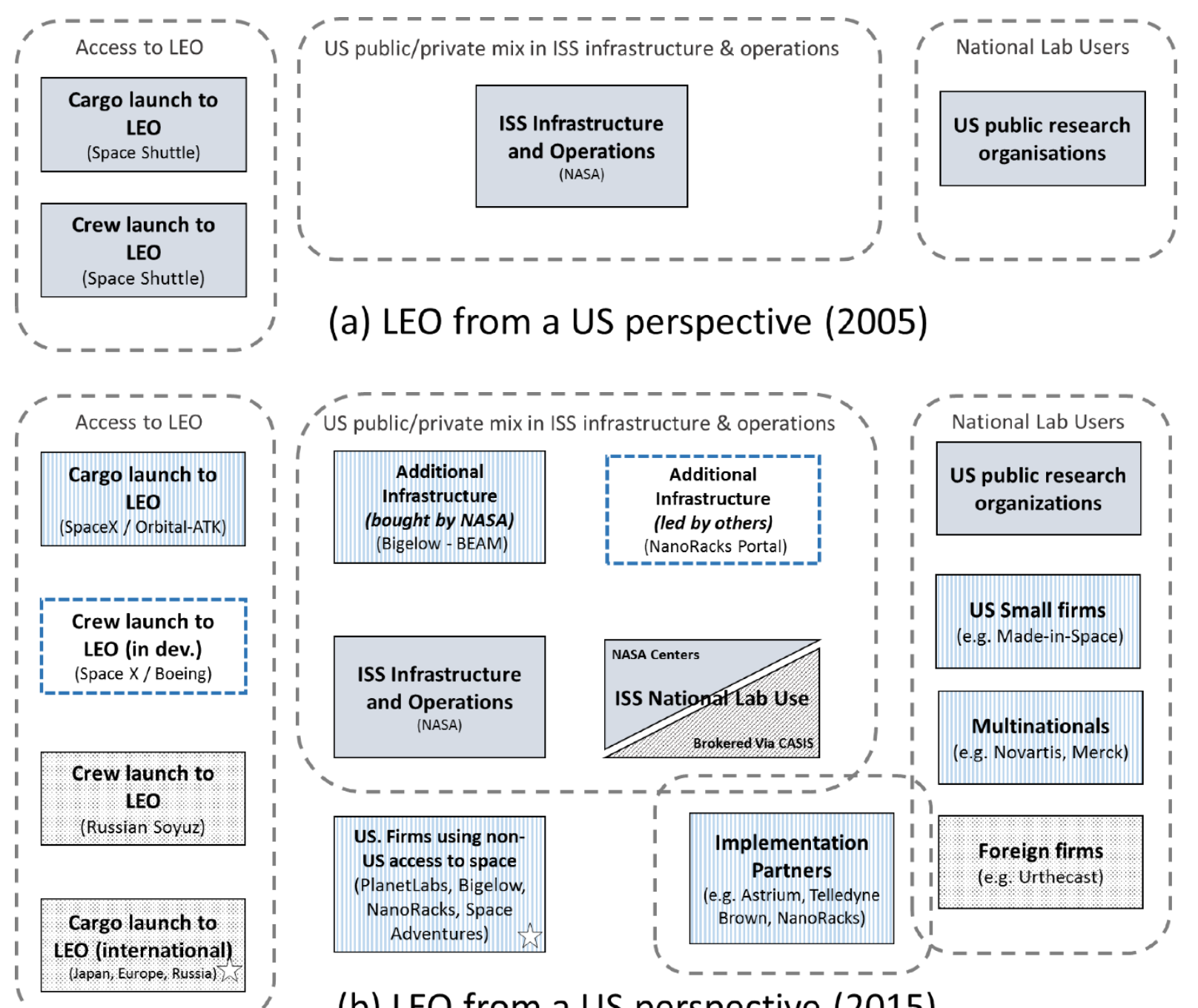

\section{(b) LEO from a US perspective (2015)}

Public organization

Not-for-profit org.

Private actor

Non-US actor

Private activity (in development)

Part b of figure 2 represents the LEO ecosystem in 2015. Regarding access to LEO, there are now four elements. Cargo delivery to LEO is now made available by the private sector (SpaceX and Orbital-ATK), but transport of the US crew to LEO requires the purchase of seats on the Russian Soyuz. NASA-funded private-sector crew delivery systems where the difference lies in the direction of design and development lies with the private sector and NASA buying services from them (examples include Boeing and SpaceX).

Another significant change from the situation in 2005 to that of 2015 is the delegation of 50 percent of ISS use to CASIS, a not-for-profit broker that mobilizes an array of private sector implementation partners, subsidized by NASA to help users make use of the US National Lab. Other commercial brokers exist, such as NanoRacks (not limited to the US National Lab) and Space Adventures (which brokers flights to the space station on the Russian Soyuz). Importantly, all elements (except the two with a white star) are financed fully or partially by NASA. This indicates a shift from vertical policies towards horizontal policies, with delegation of power to manage and orient space activities to non-NASA organizations (see section 1). To be able to understand to what extent this is true, we must zoom into the 
actual details of these new actors and their interactions in the innovation ecosystem, which we will do in the following section.

\section{An emerging ecosystem? Four types of partnerships in the new phase of LEO}

In this section we don't only look at the type and number of actors but focus in on the types of relationships between them, i.e. and ecosystem perspective. To do so, we have clustered these relationships into four kinds of partnerships: (i) new procurement approaches to stimulate a privatesector-run Earth-LEO cargo and crew delivery capability, (ii) new LEO utilization brokers that facilitate exploitation of the ISS, (iii) private sector activity building on initial NASA high risk investments, and (iv) nurturing of start-ups and small firms for the creation of new markets and new forms of value creation. We shall present each approach in brief along with some illustrative examples drawn from the LEO ecosystem.

\subsection{New procurement to stimulate private sector provided launch services ${ }^{22}$}

In 2005, the establishment of the NASA Commercial Crew \& Cargo Program Office (C3PO) resulted in two key programs to provide a national private-sector capability of transporting cargo and crew to the International Space Station. The first was the Commercial Orbital Transportation Services Program (COTS), which was launched in 2006 to provide cargo transport to the space station. The second was the Commercial Crew Development Program (CCDev), launched in 2009 to provide the transportation of crew to the ISS, taking over the role of the shuttle, which was planned to be decommissioned in 2011 (NASA 2014).

A key element of this multi-billion dollar investment was a shift in the approach of engaging with the private sector. As described in section 3, the founding legislation in 1958 provided NASA with the ability to enter into and perform contracts, leases, cooperative agreements, or other transactions to achieve its missions. Providing this 'other transactions authority' to NASA allowed it great flexibility in terms of creating partnerships and agreements with other parties outside the traditional contract approach. This authority has been operationalized into the form of Space Act Agreements (SAAs) ${ }^{23}$, which have become a key format for agreements between NASA and the private sector. The SSA's have been described as a new way of fostering interaction between NASA and the private sector, beyond traditional Federal Acquisition Regulations (FAR) cost-plus contracts. ${ }^{24}$ The application of the SAA in COTS and CCDev has meant more control of design and development shifting to the contracted firm: the key milestones and the associated price are defined by the private contractor, which means they must deliver on time or not get paid. ${ }^{25}$ By providing the company with freedom to define and deliver a service or technical capability in a way they themselves define, NASA's involvement in the process is reduced with what is argued as a broader reduction in cost (NASA 2014). It also shifts some of the risk away from NASA, which can use the milestones that the contracted company sets out in the agreement to evaluate the progress of the

\footnotetext{
22 This section has benefited from interviews with Orbital-ATK and SpaceX.

${ }^{23}$ See this link for the Space Act Agreement concerning this partnership: http://www.nasa.gov/sites/default/files/files/SAA0-SOMD11096_signed.pdf

24 During the ISS Program, NASA has made 29 major contracts with a value of $\$ 32$ billion. Fifteen of these are FAR cost-plus with a current combined total value of $\$ 22.4$ billion. This category includes the Boeing Contract, which was made in 1995 and renewed in 2010 and was valued at just over $\$ 17$ billion. Source: NASA (2014b) Extending the Operational Life of the International Space Station until 2024: NASA Office of Inspector General, 2014.

${ }^{25}$ This is in stark contrast to the FAR-Cost+ form of contract, where NASA must foot the bill if there are delays or digressions.
} 
contract. This milestone approach has meant that companies have had to deliver on time in order to be able to continue the contract. ${ }^{26}$

However, a recent report from the NASA Office of Inspector General (OIG) is suspicious of such claims, arguing that NASA in its early estimates of cost of commercial spaceflight used the cost of a seat on a Russian Soyuz spacecraft as the benchmark. However, the OIG's independent government cost estimates suggest that the costs of commercial crew transportation would be considerably higher than those of the Soyuz. ${ }^{27}$ This approach of evaluating and potentially ceasing an agreement has already been exercised. Two companies - SpaceX and Rocket Plane Kistler - were originally selected for the first round of COTS funding. However, based on the milestone approach and using this as an evaluation criteria, Rocket Plane Kistler was not awarded funding from the COTS program, whereas SpaceX was successful and continued to the next step. NASA then started funding Orbital-ATK to develop its proposal. At the time of writing, six SpaceX CRS craft and three Orbital-ATK spacecraft have been launched to LEO.

Table 1: Contracts and agreements in Earth-LEO transportation systems ${ }^{28}$

\begin{tabular}{|l|l|l|l|}
\hline $\begin{array}{l}\text { Space Act Agreement or } \\
\text { FAR Cost+ Contract }\end{array}$ & Awarded parties & Activity & \multicolumn{2}{|l|}{ Investment from NASA } \\
\hline $\begin{array}{l}\text { Commercial Orbital } \\
\text { Transportation Services } \\
\text { (COTS) }\end{array}$ & Orbital and SpaceX & $\begin{array}{l}\text { Orbital cargo } \\
\text { delivery services } \\
\text { to LEO }\end{array}$ & $\begin{array}{l}\text { \$891M } \\
\text { Space Act Agreements }\end{array}$ \\
\hline $\begin{array}{l}\text { Commercial Resupply } \\
\text { Services (CRS) }\end{array}$ & Orbital and SpaceX & $\begin{array}{l}\text { Cargo resupply } \\
\text { services to the } \\
\text { space station }\end{array}$ & $\begin{array}{l}\text { \$50M } \\
\text { FAR Cost+ contract }\end{array}$ \\
\hline $\begin{array}{l}\text { Commercial crew } \\
\text { Development Round 1 } \\
\text { (CCDev1) }\end{array}$ & $\begin{array}{l}\text { Blue Origin, Boeing, } \\
\text { Paragon, Sierra Nevada } \\
\text { and United Launch } \\
\text { Alliance }\end{array}$ & $\begin{array}{l}\text { LEO and new } \\
\text { concepts }\end{array}$ & $\begin{array}{l}\text { \$315M } \\
\text { Space Act Agreements }\end{array}$ \\
\hline $\begin{array}{l}\text { Commercial Crew } \\
\text { Development Round 2 } \\
\text { (CCDev2) }\end{array}$ & $\begin{array}{l}\text { Blue Origin, Boeing, } \\
\text { Sierra Nevada, SpaceX }\end{array}$ & $\begin{array}{l}\text { Elements of a } \\
\text { crew transport } \\
\text { system }\end{array}$ & $\begin{array}{l}\text { \$1.1B } \\
\text { Space Act Agreements }\end{array}$ \\
\hline
\end{tabular}

To avoid crowding out the competition, and to maintain a broader portfolio of potential partners, NASA experimented with an Unfunded Space Act Agreement, whereby companies could remain in the 'game' by having access to some of NASAs facilities for free. This would enable them to maintain their opportunity to compete, but they would not receive any financial assistance. ${ }^{29}$ At the time of writing, the final COTS milestones have been delivered by both SpaceX and Orbital-ATK. Through FAR-based fixed-price contracts, SpaceX has been contracted to deliver twelve commercial resupply service (CRS) flights to ISS

\footnotetext{
${ }^{26}$ As mentioned in section 3, from its initiation in 1958, the relationship between NASA and the private sector has been as (co) designer, definer of the contracts, overseer of the work being done by the contracted parties and risk-bearer if there are delays or changes to the plan. ${ }^{27}$ The study goes so far as to identify the lack of assured access to the ISS as being the highest risk when extending the operating life of the ISSS to 2024. See NASA (2014b) Extending the Operational Life of the International Space Station until 2024: NASA Office of Inspector General, 2014. http://oig.nasa.gov/audits/reports/FY14/IG-14-031.pdf ${ }^{28}$ This table is adapted from NASA (2014) Emerging Space: The evolving Landscape of 21st century Spaceflight. http://www.nasa.gov/sites/default/files/files/Emerging_Space_Report.pdf ${ }^{29}$ One example is Blue Origin, which is working on the development of its Space Vehicle for carrying people to LEO. It has been working on its propellant tank assembly via such an unfunded SAA (through CCDev2), which will last until 2016. Blue Origin benefits from access to NASA facilities and expertise to achieve this goal. More details at: https://www.nasa.gov/centers/kennedy/news/releases/2014/release20141222b.html
} 
(at a price of $\$ 1.6$ billion) ${ }^{30}$ and Orbital-ATK has been contracted for eight flights (at a price of $\$ 1.9$ billion). In terms of crew transportation, a large number of milestones have been achieved, and Boeing and SpaceX have been selected to deliver crew to the ISS in late 2017 or 2018. This approach of interaction with the private sector shares some of the risk, although the companies are subsidized by NASA via the milestone approach, through the SAA. This form of technology procurement (Edler and Georghiou, 2007; Weiss, 2014) makes it possible to build a technological capability and a supply chain to meet NASA's desire for an American supplier of services, rather than depending on European, Japanese, and Russian suppliers for cargo delivery, and Russian crew transportation (see Figure 1b). The relationship stimulates innovation and knowledge building in the private sector, something that was traditionally a large part of the public sector through NASA's Apollo and Shuttle programs.

\subsection{New LEO innovation brokers that facilitate commercialization of the ISS}

A new type of actor that has emerged over the past six years is that of brokers. Brokers in LEO are positioned between the sources and users of LEO resources for the purpose of research and innovation (Winch and Courtney, 2007; Klerkx and Leeuwis, 2009). Brokers navigate the complex constellation of actors involved in the LEO ecosystem in order to connect potential users of the ISS with NASA and 'implementation partners' - that is, those who build, fly, test, and operate the device, instrument or experiment that will operate on the ISS. ${ }^{31}$ In the US activity of the ISS, there are two brokers: NanoRacks (a firm) and the Center for the Advancement of Science in Space (CASIS), which is a not-for-profit organization. $^{32}$

NanoRacks is a Texas-based company that was founded in 2009 to take advantage of the capabilities available on a fully operational ISS. Founded by Jeffrey Manber, NanoRacks built on the past experience of its director in brokering activities in LEO, particularly the first contract between NASA and RSC Energia, as well as leasing the Russian space station Mir through his company MirCorp. ${ }^{33}$ NanoRacks markets itself as a gateway to LEO, with over 200 payload launches to-date, ${ }^{34}$ providing its customers with its knowledge of NASA, Japanese, and Russian administrative systems to get a payload onto the ISS, as well as offering a number of technical facilities, such as a commercial plug-in-and-play laboratory on the ISS and a small satellite deployer. ${ }^{35}$ In March of 2015, NanoRacks received its external payload platform and an experimental platform developed by Airbus DS Space Systems Inc., which will be attached to the space station later in 2015 (launched by the Japanese) ${ }^{36}$ NanoRacks' clients range from university groups to hobbyists, from small and large firms to public agencies such as NASA research centers themselves.

NanoRacks has an SAA with NASA but no contracts. This means that, for its business operations on the US National Lab, NanoRacks benefits from no-cost access to upmass on NASA launchers and US National Lab facilities, while NASA benefits from the users that NanoRacks brings to the ISS through its

\footnotetext{
${ }^{30} \mathrm{Half}$ of which have been delivered: $\mathrm{http}: / /$ www.americaspace.com/?p=79770

${ }^{31}$ For an example of types of implementation partners, see the partner directory of the largest ISS broker, CASIS, which provides details of the partners and their capabilities. The directory can be found at http://www.iss-casis.org/portals/0/docs/casis-partner-directory-.pdf

32 Another US Space company that also acts as a broker is Space Adventures, which focuses on space tourism and has brokered seven trips to the ISS via the Russian partners. The brokering activities of Space Adventures are not described in detail here since the company does not directly involve NASA (the subject of this section). However, we will come back to space adventures in the discussion because of its importance in US involvement in the space tourism industry.

${ }^{33}$ Source: Interview with NanoRacks Managing Director Jeffrey Manber.

${ }^{34}$ www.nanoracks.com

35 The small satellite deployer, through NanoRacks from the Japanese part of the space station, is providing a completely new way of launching small satellites. Recent users include PlanetLabs (www.planet.com), which uses a business model of launching many small satellites with a short lifetime, to be able to take real-time images of Earth and leverage this data for many sectors.

$36 \mathrm{http}: / /$ nanoracks.com/external-payload-platform-ready-for-space-station/
} 
brokering. Since 2011, however, for the US National Lab, NanoRacks now brokers with another broker, CASIS.

As part of the NASA Authorization Act of $2010,{ }^{37}$ the US Congress directed NASA to create a cooperative agreement with a not-for-profit organization to manage the ISS US National Laboratory. ${ }^{38} \mathrm{~A}$ call for proposals was issued and in 2011 CASIS was awarded the management of 50 percent of the US National Lab, and associated upmass and downmass. Operating costs for the organization were set at $\$ 15$ million per year from NASA to CASIS, including approximately $\$ 4$ million for technology development and demonstration projects. ${ }^{39}$ CASIS was set up to promote scientific research on the US National Lab by soliciting potential users, which it did by issuing calls for proposals, informed by an advisory panel of experts and their own internal review on areas of societal value. Areas included Earth observation for energy innovation, protein crystallization for health, etc. Part of the task of CASIS was to acquaint new potential users with the possibilities in terms of R\&D on the US National Lab. However, a recent NASA report argues that both NASA and CASIS have found it difficult to attract significant use of the ISS. ${ }^{40}$ Of particular concern for the authors of the report were the difficulties in attracting private funding (only $\$ 14,550$ in cash donations until the summer of 2014). The report highlights other challenges that CASIS and NASA have to face when trying to commercialize the US National Lab. There are two particular challenges in this regard: (a) that the research that can be done on the ISS is mostly basic research, as opposed to applied research; and (b) that sufficient funding must be made available from the public sector for proof-of-concept $R \& D$ in order to persuade private partners to finance further $R \& D$. In 2015 , to engage with this issue, CASIS changed its strategy to a "commercialization approach" ${ }^{41}$ with a "proactive policy" of engaging directly with existing industrial stakeholders to make us of the ISS as an $\mathrm{R} \& \mathrm{D}$ lab that can add to or stimulate new product development processes. In this way, it is the private sector (existing firms) that define what areas are of value. Their emphasis is on bringing the ISS into an existing company's portfolio of facilities to add value to their business, thereby stimulating economic benefit. CASIS also focuses on building up thematic areas of research on the US National Laboratory, as well as linking up with regions through space grants and building stronger ties with areas (such as the Galactic Grant with Massachusetts Life Science hub) to stimulate demand in the use of microgravity in certain areas of research and development.

It is clear that there is a strong shift from internally developed calls for proposals (solicitations) towards proactively engaging with firms and targeting CASIS activities based on these interactions. ${ }^{42}$ This activity resembles the business model of NanoRacks, where it is guided by industry and market opportunities. An examination of the relationship between NASA and the two brokers, NanoRacks and CASIS, reveals that there is a delegation of control over the use of the ISS from NASA to intermediary organizations that broker deals between NASA and potential users. NASA generally foots the bill by providing access to space through its launches to the space station, as well as providing free access to the US National Lab. NanoRacks as a firm builds its business on brokering use of the US National Lab (and elsewhere in the space station) and actively builds markets, such as the small satellite launch system. CASIS, a not-for-

\footnotetext{
37 http://www.nasa.gov/pdf/649377main_PL_111-267.pdf

${ }^{38}$ A study had already been commissioned on what the activities of such a not-for-profit organization could look like: Pro-Orbis (2010)

Reference model for the international space station at the US National Laboratory. September 20, 2010.

39 Source: interview with Warren Bates (CASIS).

40 NASA (2014b) Extending the Operational Life of the International Space Station until 2024: NASA Office of Inspector General, 2014. http://oig.nasa.gov/audits/reports/FY14/IG-14-031.pdf

${ }^{41}$ From interview with Cynthia Bouthot (CASIS) and Brian Talbot (CASIS).

42 Source: Warren Bates (CASIS), Cynthia Bouthot (CASIS) and Brian Talbot (CASIS).
} 
profit organization, has a budget of $\$ 15$ million per year to fund its operations, and has access to 50 percent of upmass to the space station, operations on the US National Lab and downmass.

The shift towards a "commercialization approach" for CASIS means a focus on existing industrial actors and current value chains. In taking this approach, the US National Lab is a facility like another public funded laboratory. From our interviews with CASIS and with NanoRacks, issues were raised concerning the way that current agreements around intellectual property rights aid or impede private sector activity in LEO. NASA is a title-taking agency, which means that any contractor that works for NASA or uses its facilities must obtain a waiver from NASA to be able to retain the intellectual property rights of the invention. If a waiver is not obtained, NASA automatically acquires the rights for governmental use of the intellectual property. In the negotiations around its original SAA, NanoRacks rejected the first draft, which included the standard governmental provisions on intellectual property rights, claiming that this was not in line with its business model. As Jeffrey Manber noted, "If customers invest their own money and we invest our money, the customers should have rights to their intellectual property."43 NASA provided a waiver allowing NanoRacks and its customers to retain the intellectual property. In a similar vein, NASA and CASIS are working with congressional committees to amend the federal law on patents and intellectual property rights (14 CFR Part 1245) to allow the NASA administrator the authority to waive the license to any inventions made on the US National Laboratory if such licensing would "inhibit commercialization of an invention." ${ }^{44}$ Beyond the proposed changes, ${ }^{45}$ there is a question about rights to data produced on the ISS with the need for some form of provision to cover invention and also produced data produced. ${ }^{46}$

In the debate around intellectual property, with NASA providing waivers for the private sector to stimulate commercialization, and the rise of brokers, there is an open issue about the balance between risk-taking and who appropriates the rewards. The discussion centers on the private sector driving innovation by increasing the emphasis on commercialization in NASA's missions, so that the private sector activity would lead more broadly to economic growth. This is in contrast to the vertical approach that was visible in the early years of NASA and in the case of recent procurement approaches for orbital transport systems (see 4.1).

\section{4,3 Private sector activity building on initial NASA high risk investments}

Unlike the previous two arrangements of technology procurement and the brokerage of ISS utilization, the arrangement described in this sub-section is based on two visible situations where the private sector takes some risk and invests without a guarantee of success, either in terms of its missions or in terms of financial returns. We will describe two cases. One is based on space prizes awarded by NASA when an innovator successfully provides a certain capability to NASA. The other case describes the investments by Bigelow Aerospace, whose inflatable modules for in-orbit and Cis-Lunar use build on original NASA plans and IP, licensed to Bigelow Aerospace, which has invested its own capital in developing this technology itself (rather than as part of a procurement process). These two situations represent another relationship between NASA and the private sector that has been demonstrated and may be part of a future NASA innovation policy mix.

There is a long history of using prizes and awards to stimulate innovation. The \$10 million Ansari Xprize for sub-orbital space flight triggered a swath of sub-orbital development and encouraged the growth

\footnotetext{
43 http://spacenews.com/38389us-intellectual-property-rules-hinder-space-station-research/

$44 \mathrm{http}: / /$ spacenews.com/38389us-intellectual-property-rules-hinder-space-station-research/

45 Existing law: https://www.law.cornell.edu/cfr/text/14/part-1245/subpart-3

Proposed amendment : http://www.spaceref.com/news/viewsr.html?pid=46201

${ }^{46}$ From interview with CASIS portfolio manager Warren Bates.
} 
of new companies, with the winner now providing sub-orbital planes for Virgin Galactic. For NASA, challenges are identified and announced in terms of prize competitions, with the aim of creating innovations that have the potential to advance NASA's missions. One example of a NASA supported prize is the Centennial Challenge, which began in 2005. Similar to the DARPA contests (Weiss 2008), instead of using procurement in the development of a new technological capability through announcing calls for proposals, NASA announces what it would like to have achieved and leaves it to competing teams or individuals to deliver them, with cash on delivery. Consequently, the investment into developing the innovative option remains fully with the competing innovators, with only one winner gaining the cash prize. To date, approximately $\$ 6$ million has been awarded in prizes, with prizes for space suit design (such as a more dexterous space glove), regolith processing, and laser power transmission. Recent and ongoing prizes include the space robotics challenge ${ }^{47}$ and a sample return robot, the latter associated with a prize of $\$ 1.5$ million. ${ }^{48}$ The approach of prizes shifts the risk to the private sector while subsidizing the winner, and also provides a means for gathering and testing ideas from outside of NASA, similar to the idea of Open Innovation (Chesborough 2003).

Another form of NASA-private-sector interaction involves licensing IP out to firms that invest their own money to up-value it. One example of a patent deriving from the Space Shuttle program is the case of "The Right Stuff" sports rehydration drink, developed by licensing a NASA patent by an entrepreneur. ${ }^{49}$ A particular visible example of IP licensing is Bigelow Aerospace, which will demonstrate its inflatable habitation technology (Bigelow Expandable Activity Module - BEAM) on the ISS in 2015, to be attached and operated by NASA for two years. ${ }^{50}$ This example has its roots in a NASA developed concept called TransHab, which was originally a part of NASA's early designs for a mission to Mars. When that mission was cancelled, NASA scientists suggested adding it to the early designs of the ISS. When TransHab was not passed through congress, Bigelow Licensed TransHab IP from NASA (which has so far paid approximately $\$ 1$ million for this licensing). ${ }^{51}$ Beyond the licensing, the relationship between Bigelow Aerospace and NASA in terms of demonstrating the technology began with the 2000 Memorandum of Understanding to test and demonstrate an inflatable module on the ISS (with the 2002 Space Act Agreement outlining NASA's testing of the technology). By 2003, interest in such a demonstration began to wane and Bigelow Aerospace invested in developing a free flyer for launch into orbit. Its Genesis 1 and 2 space-crafts were launched from the Russian military base of Yasny in 2006 and 2007 and are still in orbit today. The potential of an inflatable demonstration on the ISS began to develop in 2009, when Charles Miller (NASA) contacted Bigelow with the idea of paying for a demonstrator. Following three years of contract negotiations (2009-2011), the Bigelow Expandable Activity Module was developed and is due for launch later in 2015 at a cost to NASA of \$17 million. In addition, Bigelow is developing its B330, which is a larger-volume habitat technology. (This would be a massive inflatable module for humans to live and work in in space or use to travel to and on the Moon.) Its main target market is other sovereign nations and providing a commercial space station for them (Canada, Saudi Arabia, and Japan have expressed interest in this regard). Bigelow is investing \$275 million into the development of the inflatable technology.

These two examples of awards and the BEAM present another form of relationship between NASA and the private sector for developing capabilities for an Earth-LEO innovation system. The prizes shift the

\footnotetext{
${ }^{47} \mathrm{https}: / / w w w . f b o . g o v / i n d e x ? \mathrm{~s}=$ opportunity\&mode=form\&id=75af469071c50e121838298cc5fafdd9\&tab=core\&_cview=1

$48 \mathrm{http}: / / w w w . n a s a . g o v / s i t e s / d e f a u l t / f i l e s / f i l e s / C C P-F a c t S h e e t-A p r i l-2014 . p d f$

${ }^{49}$ For a detailed account of the innovation journey from identifying a NASA patent, through licensing and building a business, see Terjesen (2014). The patent in question is US $5447730 \mathrm{~A}$ and the website for the drink is available at: http://www.therightstuff-usa.com/

50 Much of this example is informed by an interview between the authors and Mike Gold (director of DC operations and business growth for Bigelow Aerospace).

${ }^{51}$ From interview with Mike Gold.
} 
risk to the competitors (cash on delivery) based on challenges set by NASA. The Bigelow Aerospace example shows the up-valuing of NASA IP, in line with its original mission, but with the private sector making a large investment to develop the capability. ${ }^{52}$

\subsection{Nurturing of small firms for the creation of new markets and new forms of value creation}

Another relationship between NASA and the private sector - distinct from the three previous types of relationship - is the funding of high risk small firms to explore and develop new markets where there is little or no current value chain. Each of NASA's centers has a commercialization department and may choose to support small firms in a number of ways. Part of this type of relationship between NASA and the private sector is the NASA SBIR program, launched in 1993, which supports breakthrough technology R\&D that may benefit NASA's overall mission.

In 1982, the Small Business Innovation Research (SBIR) program and the Small Business Technology Transfer (STTR) initiative were launched, ${ }^{53}$ with the first investments made in 1983. Amidst broad concerns about the growth of economic powers such as Japan (Weiss 2008), the policy objective was to stimulate small US-based high-tech firms by supporting high-risk research and development that would provide technological innovations for public agencies to achieve their missions and for the wider market (Wallsten 2000). This occurred around the time of the 1980 Bayh-Dole Act, which focused on stimulating technology transfer and commercialization by allowing publicly funded research to be patented. It was hoped such schemes would bring back economic growth after a long economic slowdown at the end of the 1970s (Silverman et al. 2015). The SBIR program acted as a pro-active public venture capital fund for high-risk projects and was linked directly to mission-oriented agencies such as NASA, DoD, NIH, etc. Today, with more than $\$ 37$ billion spent since its initiation and more than 170,000 grants awarded, the initiative has become a major funder of high-risk innovation in the US, private venture capital investments (Block and Keller, 2012; Audretsch, 2003; Lerner, 1996). The NASA SBIR initiative continues today, providing finance for potentially high-risk ventures that are in line with NASA's current needs or potential future needs. ${ }^{54}$ The SBIR grants provide a means of financing small innovative firms in developing phase 1 and 2 technologies for the benefit of NASA operations. Using LEO utilization as an entrance point to look at NASA-SBIR, a search for the keyword 'microgravity' in the SBIR database reveals 263 NASA SBIR grants for applications relating to the microgravity environment between 1984 and 2014.

Many of these grants are in areas that currently have no supply chain or sector. One example is the firm Made-In-Space, a 3D printing start-up that now operates a printer on the ISS to produce parts on demand. We will focus on the Made-in-Space as an example of how NASA supports, in various ways, breakthrough innovation start-ups. Made-In-Space operates the printer on the ISS directly, through its own operations room. It runs the entire operation from its offices, with astronauts having only minimal involvement in operations. NASA owns the hardware and Made-In-Space operates it. NASA supported Made-in-Space in a number of ways. When the company was launched in 2010 in the apartment of one of the founders, the nascent firm approached Pete Worden, then the director of NASA Ames, to provide lab space to develop the technology, which NASA provided. This in-kind assistance enabled Made-in-Space

\footnotetext{
only buys the water when it is available.

53 Small Business Innovation Development Act of 1982, Public Law 97-219, July 22, 1982.

${ }^{54}$ For the 2015 solicitation, see: http://sbir.nasa.gov/solicit/54564/detail?!1=54577.
}

52 Another form of relationship is the situation of Hamilton Sundstrand (now UTC Aerospace Systems), which is selling NASA the water it recycles using its Sabatier Reactor System. In direct contrast to Bigelow, which sells hardware and leaves it to NASA to operate, here NASA 
to experiment and develop the technology on the site of one of its key potential users. During 2011, the company worked the zero-g printer. After preliminary demonstrations, NASA awarded a number of SBIR grants for the printer development and operations, as well as a research project on recycling materials in zero-G. The printer was launched in September 2014 and has been operating since. Future interests include manufacturing fragile large structures in space and cubesats.

Made-in-Space is just one example of this type of relationship between NASA and small firms developing high-risk innovations. Through the SBIR and other supporting initiatives, this approach provides a mechanism for creating breakthrough innovations and supporting new entrants to the space sector. Examples like Made-in-Space show that very new approaches to innovation in LEO can be achieved through such processes.

\section{Discussion}

We began the paper by describing activities in Low-Earth-Orbit with respect to research, innovation and commercialization as an innovation ecosystem. We argued that, unlike macro-level frameworks (such as National Systems of Innovation) and micro-level frameworks (actor-networks) the Innovation Ecosystem Approach is (i) located at the meso-level, (ii) places emphasis on the form and function of the relationships between actors in the ecosystem and (iii) connects to both the macro level of national space policies and the micro level of individual activities of firms and other agents.

What is very visible, is that NASA's portfolio of PPPs shows a transition from a vertical innovation policy to a more distributed horizontal innovation policy, where goals are set by multiple actors with different criteria of success and directions of development (for example the brokers). After looking at this new constellation of actors and relationships with an ecosystems perspective, what can be said about the state of the LEO innovation system and NASA's role within it?

We approach this through a number challenges which we have seen emerging from the previous sections in this paper. These challenges can be grouped into four broad questions about the factors and actors shaping the destiny of the LEO ecosystem:

1. DIRECTIONALITY. Is the increasing emphasis horizontal innovation policy shaping its core mission? In particular, who is directing change in the LEO ecosystem?

2. EVALUATION. How does NASA's changing ambition (from determining direction to managing eco-system), alter the way that its actions can be assessed and evaluated, including changes in the short/long term?

3. ORGANIZATIONAL CAPACITY. Is the transition from NASA directed PPPs to a looser arrangement (including outsourcing) reducing innovation capacity within NASA itself? Is there a danger that the internal capacity to address innovation challenges will be reduced for future missions?

4. RISKS AND REWARDS. How are current public-private partnerships affecting NASA's ability to continue to fund future missions?

These broad challenges have been recognized elsewhere as key issues in making choices in terms of innovation systems and interventions (Mazzucato et al. 2015) Below we eleaborate on each of the four challenges for the low-earth-orbit innovation ecosystem.

\subsection{Directionality}

The central position of NASA in the space 'system of innovation' has meant that, for more than fifty years, NASA has directly financed technological innovation to achieve its missions, setting the directions 
of change and overseeing the private-sector companies that have been contracted to deliver the technologies. Today, the missions of technological innovation in space exploration are being broadened to include commercialization objectives. While commercialization did occur before as a spillover of the missions, commercialization is now more central to the missions themselves. An example can be seen in the Commercial Space Act of 1998:

"The Congress declares that a priority goal of constructing the International Space Station is the economic development of Earth orbital space. The Congress further declares that free and competitive markets create the most efficient conditions for promoting economic development, and should therefore govern the economic development of Earth orbital space. The Congress further declares that the use of free market principles in operating, servicing, allocating the use of, and adding capabilities to the Space Station, and the resulting fullest possible engagement of commercial providers and participation of commercial users, will reduce Space Station operational costs for all partners and the Federal Government's share of the United States' burden to fund operations. "55

Commercialization is affecting NASA's mission-oriented (vertical) innovation policy in a number of ways. As we have shown, commercialization was part of NASA's human spaceflight activities and its inorbit operations since the early 1980s during the early stages of the Shuttle program, but was part of a NASA-centered space ecosystem based on NASA oversight and direction of the private sector. In recent years, the innovation system has shifted to include more actors, devolution of the management of a large share of research and innovation activities on the ISS to private actors and intermediaries (we have labeled brokers). This shift regarding mission-oriented policy related to human spaceflight and in-orbit operations means that NASA has to handle two forms of broadening, mentioned in our Introduction: (i) a broadening of mission goals to include goals that are more economic in focus and less technological and (ii) a broadening of the number and types of actors in the innovation system. Consequently, unambiguous objectives with a clearly defined endgame are not possible in the emerging LEO ecosystem, which involves multiple actors with different motivations as well as a decentralization of power in terms of shaping and directing the ecosystem.

The degree of decentralization is different for various parts of the ecosystem. What is clear is that the private sector is becoming a prominent actor in the directionality of the LEO eco system. Table 2 provides an overview of the four approaches described in section 4. What is clear in this table is that the current 'public-private partnership' mix favors a market-led or bottom-up approach. The only area in which NASA has a strong direction-setting role is with the CCDev and COTS initiatives for creating a privatesector-led supply chain, whereby US launch services to LEO would be provided entirely by private-sector service providers. This is already the case for cargo to LEO, where SpaceX and Orbital-ATK have transitioned to the FAR Cost+ contracts as a launch service. SpaceX already has non-NASA contracts for launching Communication Satellites, which means that, for cargo, US launchers are fully private. For human transportation, CCDev is still in development, with the first privately crewed visits to the ISS slated for the end of 2017 or 2018 by Boeing and SpaceX. Therefore, by 2018, all launchers to LEO will be provided by the private sector and directionality will be market-led. If this mix outlined in table 2 continues, it means that NASA will have a weak "vertical" directing role.

With the presence of brokers of the "use" of the ISS National Lab, there is an increasing move towards commercial drivers for determining what activities will be conducted on the ISS National Lab. For CASIS, this manifests in its strategy to link with existing firms and connect with value chains in areas

55 The Commercial Space Act of 1998 (Public Law 105-303). Accessible at: http://www.nasa.gov/offices/ogc/commercial/CommercialSpaceActof1998.html 
such as the pharmaceutical industry and advanced materials. For NanoRacks, it is about finding novel uses of existing (or slightly modified) capabilities, as illustrated by the small satellite deployer, which has created a new market with only minor developments in technical capability. The emphasis on market demand, by linking up with the private sector and focusing on commercialization rather than NASA's mission-led use of 50 percent of the US National Lab, could raise the question of whether large amounts of innovation is likely in such a situation where there is emphasis on product creation and commercialization rather than breakthrough innovation. Again, NASA is delegating some of its power in directing the exploitation of LEO for innovation led wealth creation, to the private sector.

Table 2: Four innovation policy approaches to commercialization and supporting market creation in the LEO ecosystem

\begin{tabular}{|c|c|c|c|}
\hline & Directionality & Risk and Rewards & Who is directing? \\
\hline $\begin{array}{l}\text { New forms of } \\
\text { Procurement using } \\
\text { SAA } \\
\text { (emphasis on Earth- } \\
\text { LEO transportation) }\end{array}$ & $\begin{array}{l}\text { Vertical (moving } \\
\text { to Horizontal) }\end{array}$ & $\begin{array}{l}\text { Risk and rewards } \\
\text { shared, between the } \\
\text { public agency (who } \\
\text { foots the bill but } \\
\text { gains transport } \\
\text { services) and the } \\
\text { SAA contractor. }\end{array}$ & $\begin{array}{l}\text { NASA is directing in terms of } \\
\text { developing a capability and paying } \\
\text { for services. Use of fixed-term } \\
\text { contracts. Beyond those contracts, } \\
\text { uncertainty on the development of } \\
\text { future launch capabilities. Examples } \\
\text { include SpaceX, Orbital-ATK, } \\
\text { Boeing }\end{array}$ \\
\hline $\begin{array}{l}\text { Brokering } \\
\text { (emphasis on use of the } \\
\text { ISS) }\end{array}$ & $\begin{array}{l}\text { Horizontal } \\
\text { (Market led) }\end{array}$ & $\begin{array}{l}\text { Use of the ISS is } \\
\text { fully subsidized by } \\
\text { NASA. }\end{array}$ & $\begin{array}{l}\text { Brokers have a strong influence over } \\
\text { what is done on the ISS. For both } \\
\text { brokers, this is directly influenced by } \\
\text { the clients. Examples include CASIS } \\
\text { and NanoRacks }\end{array}$ \\
\hline $\begin{array}{l}\text { Private sector } \\
\text { investing building on } \\
\text { initial NASA } \\
\text { investments } \\
\text { (emphasis on } \\
\text { stimulating private } \\
\text { solutions to NASA } \\
\text { needs) }\end{array}$ & $\begin{array}{l}\text { Horizontal } \\
\text { (Market led) }\end{array}$ & $\begin{array}{l}\text { Risk taken and } \\
\text { rewards received by } \\
\text { the licensing actor or } \\
\text { competitor for the } \\
\text { space prize. }\end{array}$ & $\begin{array}{l}\text { NASA creates opportunities for the } \\
\text { private sector to provide solutions to } \\
\text { support NASA's missions. Example } \\
\text { includes Bigelow and The Right } \\
\text { Stuff. }\end{array}$ \\
\hline $\begin{array}{l}\text { SBIR } \\
\text { (and other small } \\
\text { business support } \\
\text { activities) }\end{array}$ & $\begin{array}{l}\text { Vertical } \\
\text { (innovation led) }\end{array}$ & $\begin{array}{l}\text { Fully subsidized by } \\
\text { NASA }\end{array}$ & $\begin{array}{l}\text { NASA funding high risk potentially } \\
\text { breakthrough technologies through a } \\
\text { number of stages of finance. } \\
\text { Examples include Made-in-Space. }\end{array}$ \\
\hline
\end{tabular}

\subsection{Evaluation/Assessment}

Traditional market failure approaches to industrial and innovation policy have developed concrete indicators and other approaches to evaluate the impact and effects of governmental investments, mainly based on cost-benefit analysis. However, these indicators, often static measures, fail to capture the dynamic character of economic development. To inform interventions in the LEO ecosystem, a number of issues must be addressed to be able to inform on evaluating the effectiveness of (and approaches to) 
intervention. One issue is the need for near real-time assessment processes for high risk investments such as in the space sector. Another is that, due to the complexity of space technology development, time horizons are important. Short to mid-term profits for the private sector versus the longer-term creation of a whole new infrastructure will be important considerations and a challenge if holistic evaluation criteria are to be developed (perhaps it will be easier to see private sector impacts on shorter turn around activities as opposed to longer term infrastructure developments made by the public sector).

\subsection{Organizational capacity}

With the devolution of LEO innovation activities to the private sector, a key question for NASA as the agency responsible for US civilian space activities is the maintenance of the ability or capacity to intervene and shape LEO activities if necessary. In the context of another mission-oriented agency, the Department of Defense, Mowery (2012) observed that, in addition to R\&D expenditure supporting weapons development, the DoD often funds $R \& D$ in peacetime with the aim of making future weapons possible, and to provide knowledge to help it decide what kinds of weapons to try to develop and ultimately to procure and use.

It is important to consider whether and how the increasing use of outsourcing of innovation activity in LEO could potentially reduce the internal capacity of NASA for its future exploration missions. Is NASA still able to accumulate the kind of knowledge and expertise (and attract the talent needed) that were essential for the Apollo and Shuttle periods of US space activities? Outsourcing space transportation to the private sector offers advantages in terms of improved cost and time to delivery, which means that the knowledge being accrued lies in the private domain. What does this mean for NASA's organizational capacity to absorb new knowledge and embark on further technology developments? Is there a danger of reducing its internal capacity to address the innovation challenges for future missions? For private-sector companies, this is referred to in terms of 'absorptive capacity'; that is, the degree to which engaging in the actual process of R\&D opens up your capacity to foresee, understand and absorb new technological opportunities, even when these are unrelated to your own R\&D (Cohen and Levinthal 1989). In sum, NASA should be careful to continue to nurture its own 'absorptive capacity' if it wants to remain a mission oriented innovation based agency.

This is a key issue going forward. There are historical precedents in terms of heavy-lift launch vehicles, where the reduction in using the Saturn V rocket has meant new investment into the development of heavy-lift launch vehicles that can take astronauts beyond LEO. There may also be a similar situation in terms of next-generation orbital platforms. There is currently no clear indication of a publicly funded orbital platform, and thus this creates uncertainty for NASA's microgravity-based R\&D, as well as the funds for the 'Journey to Mars'.

\subsection{Risks and Rewards}

Commercial activities on the US National Lab are now subsidized by US taxpayers ${ }^{56}$ and brokered via CASIS. The argument put forward is that providing the ISS facility for free to the private sector would

${ }^{56}$ Figure $1 \mathrm{~b}$ implies a flourishing LEO ecosystem in the making, with many types of actors involved. What is less visible in the diagram is that NASA subsidizes most of the activities shown in this schematic. In terms of resources, NASA bears the brunt of financial expenditure in all of the activities shown in Figure $1 \mathrm{~b}$ discussed (except those labeled with a yellow star). In terms of NASA's internal innovation capacity, the four approaches show a considerable outsourcing of innovation, whether in the form of large companies designing and creating knowledge about 
stimulate the creation of knowledge, trigger innovation and contribute to national economic growth. With the focus of activities on the ISS on demonstration and proof-of-utility (rather than full production) ${ }^{57}$ our research found no discussions of where future resources for the maintenance and further investments in ISS-like orbital facilities would come from to allow for the possibility of beyond proof-of-concept market development, for example in protein crystals or in production of advanced materials. From this perspective, one could argue that there are two overlapping and entangling systems. The first is one could be labeled the LEO ecosystem, with activities focused on both exploration and exploitation of LEO The second, can be labeled the US National Innovation System, which is comprised of many sectors and value chains and carried by a more diverse constellation of actors and activities. The policy challenge is how to connect the two systems to create economic wealth for the U.S. tax payer, as well as maintain a sustainable U.S. presence in LEO. In the current arrangement for LEO, one sees horizontal (or passive) policy of government-subsidized commercialization drive that could benefit the US National Innovation System via the private sector actors who make use of the no-cost access to the ISS and create wealth broadly.

Creating a sustainable LEO ecosystem implies one of two scenarios. Scenario 1 involves closing the financial loop between public investment of resources (NASA) to private-sector gain (subsidized users of the ISS) back to the public sector for reinvestment into space infrastructure. Scenario 2 involves closing the financial loop between public investment of resources (NASA) to private-sector gain (subsidized users of the ISS), with the private sector investing in orbital facilities to which the public sector would have access. ${ }^{58}$ Could joint ventures between the public and private sector be the way forward? Approach three in Table 2, which shifts the risk to the private sector through prizes and licensing, would provide a different policy for the LEO ecosystem. Indeed, a number of our interviewees suggested that something between licensing and a COTS-type initiative to create a next-generation ISS-type facility could be an interesting approach after its success in orbital transportation. The emphasis on the ISS's relevance to existing markets puts pressure on the access and support of potential breakthrough technologies that could create new markets. The case of Made-in-Space shows that alternative approaches to space activities are possible; in this case, with fabrication in orbit opening new possibilities for developing lightweight and fragile structures in space, which would be too delicate for launch, but it is hard to see how Made-InSpace would have emerged as a viable company without the direct support of NASA Ames and later the SBIR program This begs the question of what should be the optimum mix of approaches to create a sustainable LEO ecosystem. Another issue is intellectual property. In section 4.2 we described the ongoing discussions of waiving intellectual property rights and licensing fees to enhance commercialization. Should there be limited direct financial returns to NASA or CASIS for drug development that involves the ISS National Lab? If not a direct return to NASA or CASIS, what other deals might be possible to improve the returns to tax-payers? With the subsidizing of the LEO ecosystem, NASA assumes the risk in terms of developing and funding new space infrastructure while other actors reap the rewards, this is particularly underscored with the congressional call for an intermediary organization (CASIS) to foster ISS use. There is currently a portfolio of innovation policy approaches (see Table 2) with only approach 3 shifting the majority of the risk to the private sector.

launchers (COTS and CCDev programs), or the private sector using the ISS to further develop their products (brokered through CASIS and NanoRacks), or private sector-led initiatives (through SBIR, or the prizes and awards).

57 There are some exceptions to this. For example, services being provided such as NanoRacks satellite deployment and Made-in-Space services to replace parts. However for some of the areas that are said to be promising, for example protein crystallization and advance material development, the ISS facility allows only for proof-of-concept in LEO.

58 Other scenarios may be possible, mixing these two extremes. 


\section{Conclusion}

We have shown in this paper that there has been a considerable shift from a NASA directed US presence in LEO, to a wider and more diverse ecosystem in LEO of public and private actors, interacting through a number of different forms of relationship, though the majority of activities are still heavily subsidized by NASA.

Successful innovation in different sectors, including the commercialization of innovation, has always required both vertical and horizontal policies, and hence breaks down the usual dichotomy between vertical (active and directional) and horizontal (less 'active') policies as the way for commercialization to happen. In section 5 we have outlined four challenges that should be considered (a) how NASA can continue to direct change rather than just facilitate it, (b) the need to form new metrics to evaluate such directionality, including the problems with cost-benefit analysis; (c) the need for NASA to continue to develop its organizational structure in ways that welcomes exploration, risk and learning; and (d) the need for NASA to consider forms of contracts which allow not only the risks of innovation to be socialized, but also the rewards.

Concerning the viability of a sustainable LEO ecosystem, our interviews revealed a concern about the availability of orbital facilities beyond 2020 - there is high uncertainty about the continued access to space for further product development. With the ISS program only being planned until 2024, does a sustainable link between the LEO ecosystem and the national innovation system entail a need for next-generation orbital facilities and, if so, who should take the lead? Could it be something similar to the procurementand-use approach demonstrated by the COTS program? If so, would the use of such a facility be brokered through agents such as those present today (CASIS and NanoRacks) and how would this connect with NASA-supported breakthrough innovators such as Made-in-Space? This point raises issues in line with the three challenges outlined in section 5 regarding the mix between vertical and horizontal approaches and the risk reward balance.

To answer these questions going forward, NASA will face a number of challenges related to setting the directionality of change, building the organizations needed to do so; enabling a more dynamic evaluation of public investments; and achieving a mutualistic risk-reward relationship with the private sector.

\section{Acknowledgements}

We would like to thank firstly Alexander MacDonald, Director of NASA's Emerging Space Program, who both invited us to write this report, and provided critical feedback on various drafts. We also thank our interviewees, who provided us with a wealth of information to enhance our study: Warren Bates (CASIS), Stephanie Bednarek (SpaceX), Cynthia Bouthot (CASIS), Banning Garrett (Atlantic Council), Michael Gold (Bigelow Aerospace), Jeffrey Manber (NanoRacks), Brian Talbot (CASIS), Carl Walz (Orbital-ATK). The analysis in this paper represents the opinions and arguments of the authors only and does not reflect the opinions of NASA or the other actors that have informed our study. 


\section{REFERENCES}

Amsden, A.H. (2001). The rise of "the rest": challenges to the West from late-industrializing economies. Oxford; New York: Oxford University Press.

Anadón, L.D. (2012). Mission-oriented R\&D institutions in energy between 2000 and 2010: A comparative analysis of China, the United Kingdom, and the United States. Research Policy, 41(10), 1742-1756.

Ansari, Shahzad; Garud, Raghu. 2009. Inter-generational transitions in socio-technical systems: The case of mobile communications. Research Policy 38 (2009) 382-392.

Arrow, K. (1951). An extension of the basic theorems of classical welfare economics. Paper presented at the Second Berkeley Symposium on Mathematical Statistics and Probability, Berkeley.

Asheim, B. T., Nauwelaers, A., \& C Tödtling, F. (2003). Regional Innovation Policy for Small-Medium Enterprises. Edward Elgar Publishing.

Auerswald, P. E. and L. M. Branscomb (2003). Valleys of Death and Darwinian Seas: Financing the Invention of Innovation Transition in the United States. Journal of Technology Transfer, 28(3-4), 227239.

Audretsch, D. B. (2003). Standing on the shoulders of midgets: The US Small Business Innovation Research program (SBIR). Small Business Economics, 20(2), 129-135.

Autio, E., Kenney, M., Mustar, P., Siegel, D. and Wright, M., 2014. Entrepreneurial innovation: The importance of context. Research Policy, 43(7), pp.1097-1108.

Block, F. (2008). Swimming against the current: The rise of a hidden developmental state in the United States. Politics \& Society, 36(2), 169-206.

Block, F., \& Keller, M. (2011). State of innovation: the U.S. government's role in technology development. Boulder: Paradigm.

Bonvillian, W. B., \& Van Atta, R. (2011). ARPA-E and DARPA: Applying the DARPA model to energy innovation. The Journal of Technology Transfer, 36(5), 469-513.

Borrás, S. (2003). The innovation policy of the European Union: from government to governance. Edward Elgar Publishing.

Brown R. and Zoller, L. K. (1981) Avenues and Incentives for Commercial Use of a Low-Gravity Environment. NASA Technical Paper 1925.

http://ntrs.nasa.gov/archive/nasa/casi.ntrs.nasa.gov/19810024749.pdf

Callon, M., Laredo, P., Rabeharisoa, V., Gonard, T., \& Leray, T. (1992). The management and evaluation of technological programs and the dynamics of techno-economic networks: The case of the AFME. Research Policy, 21(3), 215-236.

Cantner, U., \& Pyka, A. (2001). Classifying technology policy from an evolutionary perspective. Research Policy, 30(5), 759-775.

CASIS (2013) The 2012 CASIS Annual Report. Available at http://ww2.isscasis.org/Casis_Annual_Report_2012 
Chang, H.-J. (2002). Kicking Away the Ladder: Development Strategy in Historical Perspective: Anthem Press.

Chesbrough, H. W. (2003). Open innovation: The new imperative for creating and profiting from technology. Harvard Business Press.

Chesbrough, H., Sohyeong, K., \& Agogino, A. (2014). Chez panisse:: building an open innovation ecosystem. California management review, 56(4), 144-171.

Chiang, J.-T. (1991). From 'mission-oriented' to 'diffusion-oriented' paradigm: the new trend of US industrial technology policy. Technovation, 11(6), 339-356.

Cohen, W. M., \& Levinthal, D. A. (1989). Innovation and learning: the two faces of R \& D. The economic journal, 569-596.

Connolly, J. F. (2006). Constellation program overview. NASA Presentation. http://nasausa.de/pdf/163092main_constellation_program_overview.pdf

DePasquale, Dominic and Elizabeth Buchen. 2014 Nano/Microsatellite Market Assessment. Atlanta, GA: SpaceWorksEnterprises, 2014.

http://www.sei.aero/eng/papers/uploads/archive/SpaceWorks_Nano_Microsatellite_Market_Assessment_ January_2014.pdf

Edler, J., \& Georghiou, L. (2007). Public procurement and innovation-Resurrecting the demand side. Research Policy, 36(7), 949-963.

Edquist, C. (2001). The Systems of Innovation Approach and Innovation Policy: An account of the state of the art. In DRUID Conference, Aalborg (pp. 12-15). Available at:

http://citeseerx.ist.psu.edu/viewdoc/download?doi=10.1.1.336.4438\&rep=rep1\&type=pdf

Edquist, C., \& Zabala-Iturriagagoitia, J. M. (2012). Public Procurement for Innovation as missionoriented innovation policy. Research Policy, 41(10), 1757-1769.

Epstein, J. (2012). Panel V: Clustering Around the Lab—Best Practices in Federal Laboratory Commercialization. See http://www.ncbi.nlm.nih.gov/books/NBK115038/?report=printable

Falck, O., Gollier, C., \& Woessmann, L. (2011). Arguments for and against Policies to Promote National Champions. In O. Falck, C. Gollier \& L. Woessmann (Eds.), Industrial Policy for National Champions (pp. 3-9). Cambridge, MA: MIT Press.

Flanagan, K., Uyarra, E., \& Laranja, M. (2011). Reconceptualising the 'policy mix' for innovation. Research Policy, 40(5), 702-713.

Foray, D., Mowery, D. C., \& Nelson, R. R. (2012). Public R\&D and social challenges: What lessons from mission R\&D programs? Research Policy, 41(10), 1697-1702.

Fransman, M. (2002). Mapping the evolving telecoms industry: the uses and shortcomings of the layer model. Concept Paper. University of Edinburgh: School of Economics. 2002

Freeman, C., \& Soete, L. (1997 [1974]). The economics of industrial innovation (3rd ed.). Cambridge, Mass.: MIT Press.

Freeman, C. (1994). The economics of technical change. Cambridge journal of economics, 463-514. 
Friedman, B.M. (1979). 'Crowding out or crowding in? The economic consequences of financing government deficits'. Brookings Papers on Economic Activity, 3, 593-654.

Frosch, R. A. (1979). "NASA Guidelines Regarding Early Usage of Space for Industrial Purposes," June 25, 1979, NASA Historical Reference Collection, NASA History Office, NASA Headquarters, Washington, DC.

Funk, Jeffrey L. 2009. The emerging value network in the mobile phone industry: The case of Japan and its implications for the rest of the world. Telecommunications Policy, 33, 4-18.

Geels, F. W. (2004). From sectoral systems of innovation to socio-technical systems: Insights about dynamics and change from sociology and institutional theory. Research policy, 33(6), 897-920.

Ginzburg, E., Kuhn, J. W., Schnee, J., \& Yavitz, B. (1976). Economic impact of large public programs: The NASA experience. http://ntrs.nasa.gov/archive/nasa/casi.ntrs.nasa.gov/19760016995.pdf

Green, K., Hull, R., McMeekin, A., \& Walsh, V. (1999). The construction of the techno-economic: networks vs. paradigms. Research Policy, 28(7), 777-792.

Grimwood, J. M., Hacker, B. C., \& Vorzimer, P. J. (1969). Project Gemini Technology and Operations A Chronology. http://ntrs.nasa.gov/archive/nasa/casi.ntrs.nasa.gov/19690027123.pdf

Hall, R. Cargill (1992). The Origins of US Space Policy: Eisenhower, Open Skies, and Freedom of Space. Rand Corp: Washington DC.

Hekkert, M. P., Suurs, R. A., Negro, S. O., Kuhlmann, S., \& Smits, R. E. H. M. (2007). Functions of innovation systems: A new approach for analysing technological change. Technological Forecasting and Social Change, 74(4), 413-432.

Jaffe, A. B., \& Lerner, J. (2001). Reinventing public R\&D: Patent policy and the commercialization of national laboratory technologies. Rand Journal of Economics, 167-198.

Kay, L. (2011). The effect of inducement prizes on innovation: evidence from the Ansari XPrize and the Northrop Grumman Lunar Lander Challenge. R\&D Management, 41(4), 360-377.

Kay, W.D. (1994) Democracy and super technologies: The politics of the space shuttle and Space Station. Freedom, Science, Technology and Human Values, 19(2, April), 131-151.

Klerkx, L., \& Leeuwis, C. (2009). Establishment and embedding of innovation brokers at different innovation system levels: Insights from the Dutch agricultural sector. Technological Forecasting and Social Change, 76(6), 849-860.

Kuhlmann, S. \& Edler, J. (2003). Scenarios of technology and innovation policies in Europe: investigating future governance. Technological Forecasting and Social Change, 70(7), 619-637.

Kuhlmann, S. \& Rip, A. (2015). The challenge of addressing Grand Challenges. In: von Schomberg, R. (ed.): The Future of Research and Innovation. Brussels: European Commission (in press).

Laredo, P., Jolivet, E., Shove, E., Raman, S., Rip, A., Moors, E.\& Clara Eugenia, G. (2002). SocRobust: final report.

Launius, R. D. (1994). NASA and the Decision to Build the Space Shuttle, 1969-72. Historian, 57(1), $17-34$. 
Lazzarini, Sergio G.; Chaddad, Fabio R.; Cook, Michael L. (2001). Integrating supply chain and network analyses: The study of netchains. Journal on Chain and Network Science 2001, 1(1), 7-22

Lerner, J. (1996). The government as venture capitalist: The long-run effects of the SBIR program (No. w5753). National Bureau of Economic Research.

Li, F. \& Whalley, J. (2002). Deconstruction Of The Telecommunications Industry: From Value Chains to Value Networks. Strathclyde Business School: Research Paper No 2002/2.

Logsdon, J. M. (1986). The Space Shuttle program: a policy failure? Science, 232(4754), 1099-1105.

Logsdon, J. M. (1995). The Evolution of U.S. Space Policy and Plans. In Exploring the Unknown, p. 384.

Lundvall, B. A. (1992). User-producer relationships, national systems of innovation and internationalisation. National systems of innovation: Towards a theory of innovation and interactive learning, 45-67.Malerba, F. (2002). Sectoral systems of innovation and production. Research Policy, 31(2), 247-264.

Mazzucato, M. (2000). Firm size, innovation, and market structure: the evolution of industry concentration and instability. Edward Elgar Publishing.

Mazzucato, M. (2013). The Entrepreneurial State: Debunking the Public vs. Private Myth in Risk and Innovation. London: Anthem.

Mazzucato, M. (2015). From Market Fixing to Market Creating: A New Framework for Economic Policy. SPRU Working Paper Series, 2015-25: 1-19. ISSN 2057-6668. Available at www.sussex.ac.uk/spru/swps2015-25

Mazzucato, M. (2015). “A Mission Oriented Approach to Building the Entrepreneurial State”, Report commissioned by UK government, https://www.gov.uk/government/news/long-term-growth-innovationsrole-in-economic-success

Mazzucato, M. and Penna, C. (2015) Mission-Oriented Finance for Innovation: New Ideas for Investment-Led Growth, Rowman \& Littlefield, ISBN 978-1-78348-495-9

Mazzucato, M., Cimoli, M., Dosi, G., Stiglitz, J. E., Landesmann, M. A., Pianta, M., Walz. R. \& Page, T. (2015). Which industrial policy does Europe need?. Intereconomics, 50(3), 120-155.

Mazzucato, M., \& Perez, C. (2014), Innovation as Growth Policy. In The Triple Challenge: Europe in a New Age. J. Fagerberg, S. Laestadius, and B. Martin (eds.) Oxford University Press: Oxford, forthcoming.

Mowery, D. C. (2012). Defense-related R\&D as a model for "Grand Challenges" technology policies. Research Policy, 41(10), 1703-1715.

Mowery, D. C., Nelson, R. R., \& Martin, B. R. (2010). Technology policy and global warming: Why new policy models are needed (or why putting new wine in old bottles won't work). Research Policy, 39(8), 1011-1023.

Mowery, D.C. (2010). Military R\&D and innovation. In B. H. Hall \& N. Rosenberg (Eds.), Handbook of the Economics of Innovation (vol. 2, pp. 1219-1256). 
NASA (1958) "National Aeronautics and Space Act of 1958," Public Law 85-568, as reprinted in Exploring the Unknown: Selected Documents in the History of the U. S. Civil Space Program, VOL I., Organizing for Exploration, John M. Logsden ed. (Washington, D.C.: NASA SP-4407, 1995).

NASA (2011) Voyages: Charting the Course for Sustainable Human Space Exploration. NP-2011-06395-LaRC

NASA (2014) Commercial Orbital Transportation Services: A New Era in Spaceflight. NASA/SP-2014617

National Aeronautics and Space Administration. Extending the Operational Life of the International Space Station until 2024: NASA Office of Inspector, 2014. http://oig.nasa.gov/audits/reports/FY14/IG14-031.pdf

National Commission on Space (1986). Pioneering the Space Frontier: The Report of the National Commission on Space: An Exciting Vision of Our Next Fifty Years in Space, 1986, http://history.nasa.gov/painerep/begin.html.

Nelson, R. R., \& Rosenberg, N. (1993). Technical innovation and national systems. National innovation systems: a comparative analysis. Oxford University Press, Oxford, 1-18.

NRC (2014) Pathways to Exploration: Rationales and approaches for a U.S. program of human space exploration. National Research Council. ISBN 978-0-309-30507-5.

Offenberg, J. (2001). Balancing between mutualism and exploitation: the symbiotic interaction between Lasius ants and aphids. Behavioral Ecology and Sociobiology, 49(4), 304-310.

Omta, S. W. F. O., Trienekens, J., \& Beers, G. (2001). Chain and network science: A research framework. Journal on Chain and Network Science, 1(1), 1-6.

O'Riain, S. (2004). The politics of high-tech growth: Developmental network states in the global economy: Cambridge University Press.

Peppard, Joe; Rylander, Anne. 2006. From Value Chain to Value Network: Insights for Mobile Operators. European Management Journal 24 (2-3), April-June 2006, 128-141.

Perez, C. (1983). Structural change and assimilation of new technologies in the economic and social systems. Futures, 15(5), 357-375.

Perez, C. (2002). Technological revolutions and financial capital: the dynamics of bubbles and golden ages. Cheltenham, UK; Northampton, MA, USA: Edgar Elgar.

Perez, C. (2004). Technological revolutions, paradigm shifts and socio-institutional change.

Globalization, economic development and inequality: An alternative perspective, 217-242.

Pittman, B. and Rasky, D. J. (2013) Developing Cislunar space using the COTS model. AD Astra Spring 2013. http://www.nasa.gov/sites/default/files/files/Adastra_2013_Pittman-Rasky.pdf

Polanyi, K. (2001 [1944]). The great transformation: the political and economic origins of our time. Boston: Beacon Press.

Porter, M. E. (2001). Strategy and the Internet. Harvard Business Review. March 2001, 1-19. 
Pro-Orbis (2010) Reference model for the international space station U.S National Laboratory. September 20,2010

Reinert, E.S. (2007). How rich countries got rich and why poor countries stay poor. London: Constable.

Report of the Advisory Committee on the Future of the U.S. Space Program, December 1990, http://history.nasa.gov/augustine/racfup1.htm.

Robinson, D. K. R., \& Propp, T. (2008). Multi-path mapping for alignment strategies in emerging science and technologies. Technological Forecasting and Social Change, 75(4), 517-538.

Robinson, D. K. R., Le Masson, P., \& Weil, B. (2012). Waiting games: innovation impasses in situations of high uncertainty. Technology Analysis \& Strategic Management, 24(6), 543-547.

Robinson, D. K. R. (2014) Anticipatory coordination around nanotechnology innovation systems and industries: successes, failures and muddling through. EU-SPRI conference: Science and Innovation Policy, Dynamics, Challenges, Responsibility and Practice. 18-20 June 2014, Manchester, United Kingdom.

Rodrik, D. (2004). Industrial Policy for the Twenty-First Century. John F. Kennedy School of Government Working Paper Series, rwp04-047.

Reagan, R. (1986). "Statement on the Building of a Fourth Shuttle Orbiter and the Future of the Space Program, August 15, 1986," from Public Papers of Ronald Reagan, 1986, http://www.reagan.utexas.edu/archives/speeches/1986/081586f.htm.

Rohrbeck, R., Hölzle, K., \& Gemünden, H. G. (2009). Opening up for competitive advantage-How Deutsche Telekom creates an open innovation ecosystem. R\&d Management, 39(4), 420-430.

Rumerman, J. A. (1999). NASA Space Applications, Aeronautics and Space Research and Technology, Tracking and Data Acquisition/Support Operations, Commercial Programs, and Resources, 1979-1988. NASA Historical Data Books (SP-4012) Volume VI.

Sampat, B. N. (2012). Mission-oriented biomedical research at the NIH. Research Policy, 41, 1729-1741.

Saliola, Federica; Zanfei; Antonello. 2009. Multinational firms, global value chains and the organization of knowledge transfer. Research Policy 38 (2009) 369-381.

Scanlon, Robert. 2009. Aligning product and supply chain strategies in the mobile phone industry. Ithaca/Cambridge: Cornell University/MIT, June 2009.

Schot, J. (2014). Transforming Innovation Policy. Keynote address at Edges, Horizons, and Transformations: The Future of Innovation Policy, Organized by the Science Policy Research Unit (SPRU), University of Sussex, October 21 2014, The Royal Society of Arts, London.

Smith, A., Stirling, A., \& Berkhout, F. (2005). The governance of sustainable socio-technical transitions. Research policy, 34(10), 1491-1510.

Soete, L., \& Arundel, A. (1993). An Integrated Approach to European Innovation and Technology Diffusion Policy: A Maastricht Memorandum. Luxembourg: Commission of the European Communities, SPRINT Programme.

Space Station Operations Task Force (1987). Panel 3 Report: User Development and Integration. Dec 1987. http://ntrs.nasa.gov/archive/nasa/casi.ntrs.nasa.gov/19890015875.pdf 
Stares, P. (1983). Space and US national security. The Journal of Strategic Studies, 6(4), 31-48.

Steinbock, Dan. 2003. Globalization of wireless value system: from geographic to strategic advantages. Telecommunications Policy 27 (2003) 207-235.

Stiglitz, J., \& Weiss, A. (1981). Credit rationing in markets with imperfect information. American Economic Review, 3(71), 393-410.

Stine, D. D. (2009). The Manhattan Project, the Apollo Program, and Federal Energy Technology R\&D Programs: A Comparative Analysis. Congressional Research Service, Library of Congress. http://fpc.state.gov/documents/organization/128397.pdf

Stirling, A. (2009). Direction, distribution and diversity! Pluralising progress in innovation, sustainability and development. Available at:

http://mobile.opendocs.ids.ac.uk/opendocs/bitstream/handle/123456789/2458/Direction,\%20Distribution $\% 20$ and $\% 20$ Diversity.pdf? sequence $=1$

Terjesen, S. (2014), The Right Stuff: A NASA Technology-Based New Venture and the Search for Markets on Earth. Entrepreneurship Theory and Practice. doi: 10.1111/etap.12144

Tilson, D., Lyytinen, K. (2004). The 3G Transition: Changes in the U.S. Wireless Industry. Case Western Reserve University, USA. Sprouts: Working Papers on Information Systems, 4(8).

Tullock, G., Seldon, A., \& Brady, G.L. (2002). Government failure: a primer in public choice. Washington, DC: Cato Institute.

Tsujimoto, M., Kajikawa, Y., Tomita, J., \& Matsumoto, Y. (2015, August). Designing the coherent ecosystem: Review of the ecosystem concept in strategic management. In Management of Engineering and Technology (PICMET), 2015 Portland International Conference on (pp. 53-63). IEEE.Wade, R. (1990). Governing the market: economic theory and the role of government in East Asian industrialization. Princeton: Princeton University Press.

Wallsten, S. J. (2000). The effects of government-industry R\&D programs on private R\&D: the case of the Small Business Innovation Research program. The RAND Journal of Economics, 82-100.

Weiss, L. (2008). Crossing the Divide: From the Military-Industrial to the Development-Procurement Complex. In Berkeley Workshop on the "Hidden US Developmental State" (pp. 20-21).

Weiss, L. (2014). America Inc.: Innovation and Enterprise in the National Security State. Cornell University Press, NY.

Winch, G. M., \& Courtney, R. (2007). The organization of innovation brokers: An international review. Technology Analysis \& Strategic Management, 19(6), 747-763.

Wright, B.D. (2012). Grand missions of agricultural innovation. Research Policy, 41(10), 1716-1728. 